\title{
SCIENTIFIC REP RTS OPEN Author Correction: Dynamics of the Global Wheat Trade Network and Resilience to Shocks
}

\section{Kathyrn R. Fair ${ }^{1,2}$, Chris T. Bauch ${ }^{1} \&$ Madhur Anand $^{2}$}

Correction to: Scientific Reports https://doi.org/10.1038/s41598-017-07202-y, published online 03 August 2017

The original version of this Article omitted an affiliation for Kathryn R. Fair. The correct affiliations for Kathryn R. Fair are listed below:

University of Waterloo, Department of Applied Mathematics, Waterloo, N2L 3G1, Canada

University of Guelph, School of Environmental Sciences, Guelph, N1G 2W1, Canada

This has now been corrected in the HTML and PDF versions of this Article, and in the accompanying Supplementary Information.

(c) (i) Open Access This article is licensed under a Creative Commons Attribution 4.0 International License, which permits use, sharing, adaptation, distribution and reproduction in any medium or format, as long as you give appropriate credit to the original author(s) and the source, provide a link to the Creative Commons license, and indicate if changes were made. The images or other third party material in this article are included in the article's Creative Commons license, unless indicated otherwise in a credit line to the material. If material is not included in the article's Creative Commons license and your intended use is not permitted by statutory regulation or exceeds the permitted use, you will need to obtain permission directly from the copyright holder. To view a copy of this license, visit http://creativecommons.org/licenses/by/4.0/.

(C) The Author(s) 2019 